\title{
PRODUCTION, PURIFICATION OF LOCUST BEAN GUM AND CAROB DIBIS AND THEIR APPLICATION IN MANUFACTURE OF YOGHURT
}

\author{
EL- KHOLY, WEDAD M. ${ }^{1}$, REDA A. AAMER ${ }^{2}$ and M. A. ZEDAN ${ }^{1}$ \\ 1. Dairy Research Department, Food Technology Research Institute, A.R.C., \\ Egypt. \\ 2. Department of Horticul. Crop processing, Food Technology Research Institute, \\ A.R. C., Egypt.
}

(Manuscript received 23 August 2015)

\begin{abstract}
I ocust bean gum (LBG) is used as a thickener, stabilizer, emulsifier and gelling agent in the food industry, and is approved in most areas of the world. The aim of this study was the production of carob dibis, separate and purification of LBG from seeds then investigate the effect of addition of carob dibis at the rate of $10 \%$ and LBG $(0.00,0.02,0.04,0.06$ and $0.08 \% \mathrm{w} / \mathrm{v})$ on the $\mathrm{pH}$, total solids (T.S), water holding capacity (WHC), mineral content, rheological properties, microbiological analyses and sensory evaluation of set-type yoghurts. It was found that carob dibis is a rich source of sugars and contains high concentrations of minerals. The use of LBG in the yoghurt processing affected the $\mathrm{pH}$. It was found that the water holding capacity of samples ranged from $20.15 \%$ to $23.95 \%$ during storage period. Dibis and LBG addition did not influence the counts of bacteria. The use of LBG as a stabilizer at concentration of $0.04 \%$ LBG $+10 \%$ dibis in yoghurt manufacture was the best treatment that improved the sensory and rheological properties compared with the yoghurt from the other treatments.
\end{abstract}

Key words: Carob, locust bean gum, dibis, yoghurt, textural and sensory properties.

\section{INTRODUCTION}

Yoghurt, a fermented dairy product, is produced by adding yoghurt starter bacteria in milk. It is a popular product throughout the world (Tamime and Robinson, 1999).Texture is one of the main characters that define the quality of yoghurt. Elaboration of yoghurt texture is depending on various factors, which have been extensively studied with the aim to improve this important feature for yoghurt quality. Stabilizers are commonly used in cultured products to control texture and these include locust bean gum, xanthan gum, and carrageenan, guar gum, gelatin, pectin, agar and whey protein concentrate(Lucey, 2004). Stabilizers are used in yoghurt as a single compound or as a blend and are used as thickening, stabilizing and gelling agents. The selection of a particular type of stabilizer is dependent on aspects such as functional properties, the effect, or mode of action of the stabilizer and the optimum 
concentration to be utilized. Choice of the proper type and level of hydrocolloid used is one of the most important factors in the manufacture of fermented dairy products. The addition of stabilizer to yoghurt improve body and texture, appearance and delays whey separation .

Stabilizers have two basic functions in yoghurt: the binding of water and improvements in texture (Kumar and Mishra, 2004).

The carob product most widely used, especially for the food industry is the carob bean gum (CBG), or locust bean gum (LBG), for use as a natural food additive (known as E 410). LBG is the milled and purified endosperm of seeds of carob that is mainly used in food and nonfood products as thickening and stabilizing agents. The chemical composition ( $88 \%$ galactomannans, $5 \%$ other polysaccharides, $6 \%$ protein, and $1 \%$ ash of LBG) plays an important role in their rheological properties (Kök, 2007).

In recent years, the use of carob dibis has been rapidly increased because of its nutritional properties such as their minerals content $(\mathrm{K}, \mathrm{Ca}, \mathrm{Fe}, \mathrm{P}$ and $\mathrm{Mg}$ ). Carbohydrates and organic acids are the major constituent of dibis. Dibis added to yoghurt has functional benefits further than plain yoghurt, concerning consumer health. The addition of dibis allowed enriching yoghurt with sugar, also it contains high amount of iron, which is recommended in the treatment of anemia. Researchers, who studied about molasses added yoghurt, suggested that using various stabilizers could improve textural properties which were impaired by dibis addition (Karaca, 2013).

The aim of this research was to produce carob dibis from carob pods, separation and purification LBG from carob seeds, then evaluate the physicochemical properties of carob dibis and purified LBG. Utilizating the dibis and LBG-dibis in set yoghurts. The physicochemical, rheological, and microbiological properties of yoghurt samples were determined during the storage period.

\section{MATERIALS AND METHODS}

\section{Materials:}

$5 \mathrm{~kg}$ of carob were purchased from the arid Aswan desert region of southern Egypt in November 2014. Cow, and Buffaloes milk were obtained from dairy farm of faculty of Agriculture, Alexandria University, Egypt. Skimmed milk powder was obtained from a local market. Freeze dried DVS-ABY-1Nu-TRISH yoghurt cultures containing S. salivarius subsp. thermophilus and L. delbrueckii subsp bulgaricus 
strains were obtained from Chr. Hansen Inc. Laboratories, Denmark, by Misr Food Additives (MIFAD), Egypt.

\section{Methods:}

\section{Physical Methods:}

The weight of the pods and seeds was carried out to determine the percentage of seeds and pulp of pods; the hull, endosperm and germ of seeds.

\section{Technological Methods:}

\section{Preparation of Carob Dibis}

The carob pods were immediately washed with water and dried in the oven for $30 \mathrm{~min}$. at $40^{\circ} \mathrm{C}$. The pods were then stored in dry environment at room temperature until used. The carob dibis is prepared according to the method shown in Figure (1) as cited by (Karima et al.,2014 ) with some modification Pods pulps were grounded using a blender (Kenwood major titanium, Japan) and filtration was achieved through cloth. The extract of carob was concentrated to $71^{\circ}$ Brix by rotary evaporator (Hahnvapor, Mod No. HS-2005SD, Korea). The obtained final dibis was kept in dark bottles at room temperature until used.

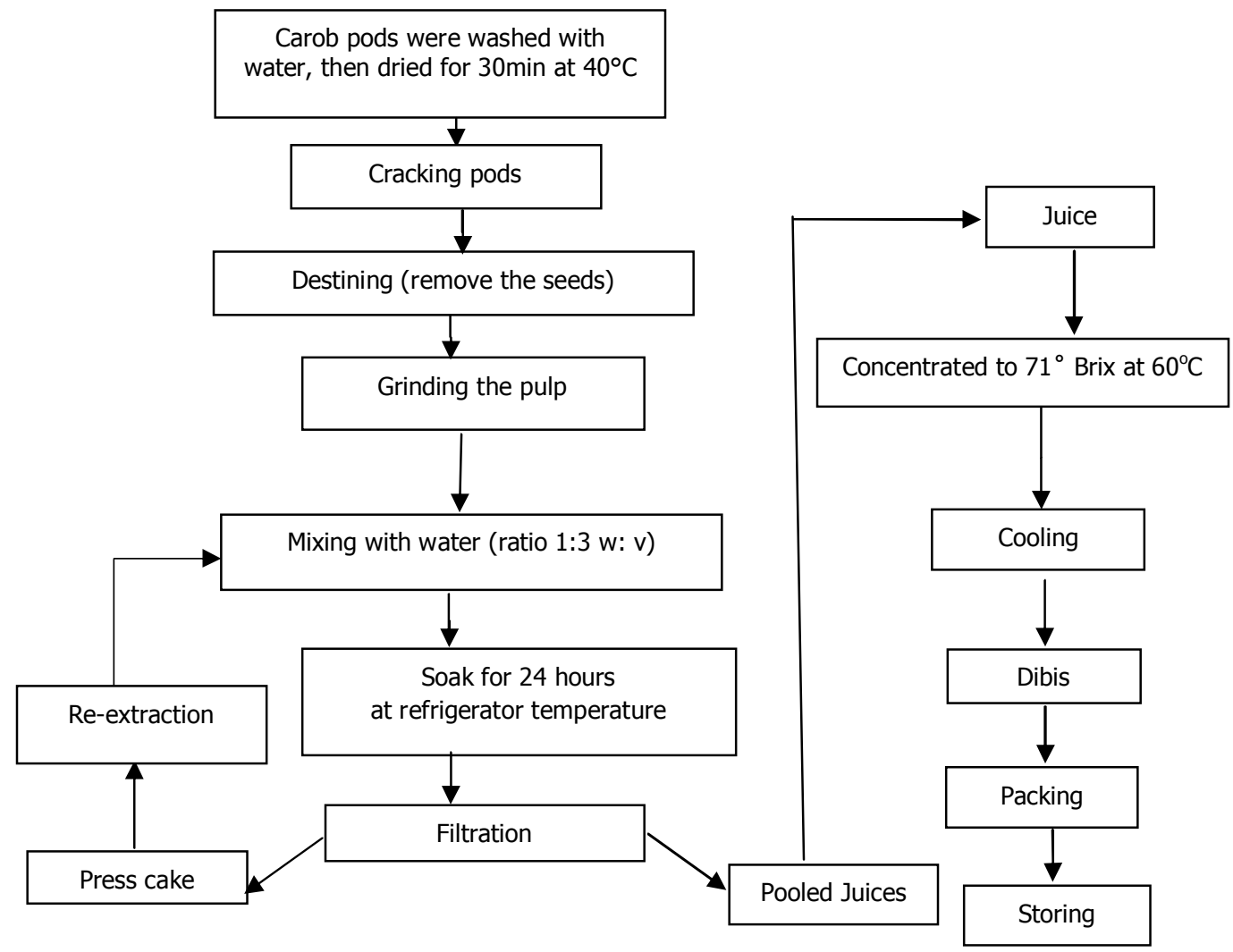

Figure 1. Preparation process of carob dibis. 


\section{Separation and purification of locust bean gum (LBG)}

An aliquot amount of carob seeds (100 g) was soaked in $800 \mathrm{ml}$ boiling water for $2 \mathrm{~h}$. followed by removing the seeds from hot water. Seed endosperms were then separated manually from the germ and hull. The separated endosperms were dried by a freeze dryer (Freezoneplus 6, Labconco, USA), milled by adisc mill and sifted with $125 \mu \mathrm{m}$ sieve to obtain crude LBG (Dakia et al., 2008).

To produce purified LBG solution, the crude LBG was purified according to the procedure of (Bouzouita et al., 2007) with some modifications. Briefly, LBG solution (include $1 \mathrm{~g} \mathrm{LBG} / 100 \mathrm{ml}$ distilled water) was prepared and heated at $80^{\circ} \mathrm{C}$ in a water bath for 30 minutes. After cooling, isopropanol alcohol was added to the solution (isopropanoal to LBG solution 2:1), mixed thoroughly and left for $120 \mathrm{~min}$ at room temperature. The white fibrous precipitate formed was then collected by filtering the mixture through a metal sieve (with opening diameter of $1 \mathrm{~mm}$ ) and washed with isopropanol twice then dried at room temperature.

\section{Yoghurt Production}

The total solid content of milk ( a mixture of $50 \%$ cow and $50 \%$ buffaloes milk) was standardized to $14 \%$ by adding ( $3 \% \mathrm{w} / \mathrm{v})$ skimmed milk powder. The levels of LBG used in yoghurt production were $(0.00,0.02,0.04,0.06$ and $0.08 \%)$. Standardized milk was divided into six equal parts. The control yoghurt (C1) was prepared from the standardized milk, while experimental yoghurts $\left(C 2, T_{1}, T_{2}, T_{3}\right.$ and $\mathrm{T}_{4}$ ) were prepared from standardized milk with added $10 \%$ dibis (Preliminary experiment was done to select the best concentration from carob dibis) and addition of $(0.00,0.02,0.04,0.06$ and $0.08 \%)$ locust bean gum (w/v), respectively. LBG used in the formulations was soaked using distilled water at $80 \pm 1^{\circ} \mathrm{C}$. The mixtures were stirred for $30 \mathrm{~min}$ on a magnetic stirrer and cooled at room temperature. Hydrated locust bean and skimmed milk powder $(3 \% \mathrm{w} / \mathrm{v})$ were mixed. All treatments were heated to $85^{\circ} \mathrm{C}$ for 15 minutes and rapidly cooled to $42 \pm 1^{\circ} \mathrm{C}$.Carob dibis were then added to five milk batches respectively at a concentration of $100 \mathrm{ml} / \mathrm{L}$. Then all batches were inoculated with yoghurt starter(S.thermophilus and L.bulgaricus $2 \%$ ), distributed in $100 \mathrm{ml}$ sterile plastic containers followed by incubation at $42 \pm 1^{\circ} \mathrm{C}$ until a pH of 4.7 was reached. After incubation yoghurt samples were cooled down and stored at $4 \pm 1^{\circ} \mathrm{C}$ for 9 days. Three replicates of set yoghurts were produced.

\section{Physico-chemical analysis}

Moisture, crude protein, fat, crude fiber and ash contents were determined according to AOAC (2007). Carbohydrate content was determined by differences of 
total contents (moisture, protein, fat, crude fiber and ash) from 100.Thetotal soluble solids (TSS) content was determined using digital refractmeter (Hanna, HI 96811, Germany). Total, reducing and non-reducing sugars were determined by the LaneEynon method AOAC (2007).The $\mathrm{pH}$ was determined using glass electrode $\mathrm{pH}$ meter (Persica model pH 900, Switzerland).The minerals ( $\mathrm{K}, \mathrm{Ca}, \mathrm{Mg}, \mathrm{Na}, \mathrm{Fe}$ and $\mathrm{Mn}$ ) were determined according to the AOAC (2007).Ca, Mg, Fe and Mn were determined using a Perkin Elmer Atomic Absorption spectrophotometer (Model 2380, Japan), while $\mathrm{K}$ and $\mathrm{Na}$ were determined by coring flame photometer(Model 410, Japan).The waterholding capacity of yoghurt samples was determined according to Arslan and Özel(2012). Triplicate measures were taken for each sample. Viscosity of the samples was determined by using a Brookfield viscometer (model DV-II + Pro, Brookfield Engineering Laboratories, Middleboro, MA, USA) at $24.8^{\circ} \mathrm{C}$ with spindle number SC415after 30s rotation of $80 \mathrm{rpm}$ (Cinbas and Yazici, 2008). The colour of carob dibis was evaluated by measuring the Hunter L, (Lightness; (100) white, (0) black), a ((+) red, $(-)$ green) and b $((+)$ yellow, $(-)$ blue) parameters with a colorimeter (Hunter Ultra Scan VIS).

\section{Rheological analyses of yoghurt sample}

Texture properties were measured at $20^{\circ} \mathrm{C}$ using a texture analyzer (TA1000, Lab Pro (FTC TMS-Pro, USA). A two-bite penetration test was performed using the Texture Analyzer with the TA17 probe (30 and $35 \mathrm{~mm}$ diameter) and operated at a crosshead speed of $1 \mathrm{mms}$ _1and penetration distanceof $10 \mathrm{~mm}$. Hardness, adhesiveness, springiness, cohesiveness, gumminess and chewiness were evaluated by the method described by (Bourne, 1978).

\section{Microbiological analyses}

The total bacterial count was determined according to (Marshal, 1992). For enumeration of $S$. salivarius subsp. thermophilus, diluted samples were cultivated on M17 agar and incubated at $30^{\circ} \mathrm{C}$ for $48-72 \mathrm{~h}$ under aerobic conditions.MRS agar was used for enumeration of L.delbrueckii subsp. bulgaricus. The plates were incubated at $37^{\circ} \mathrm{C}$ for $48-72 \mathrm{~h}$.Coliform bacteria and Moulds and Yeasts were enumerated according to standard methods for examination of dairy products (Marth, 1998) using the violet red bile agar (VRBA) and acidified potato dextrose agar (PDA), respectively. Yoghurt samples were analyzed at zero, 3, 6 and 9 days. The results were recorded as a number of colony forming units per gram $\left(\log _{10} \mathrm{cfu} / \mathrm{g}\right)$. 


\section{Sensory evaluation}

Sensory evaluation of carob dibis and yoghurt samples was done for appraising the sensory traits of the product. It was carried out by a panel consisting of 10 panelists including staff members and assistants, engineers and post graduate students at Faculty of Agriculture El-Shatby, Dairy Science Department and Food Science and Technology Department (Ranadheera et al., 2012).

\section{Statistical analysis}

All data were expressed as mean values \pm SD. Statistical analysis was performed using one way analysis of variance (ANOVA)followed by Duncan- s Multiple Range Test with $\mathrm{P} \geq 0.05$ being considered statistically significant using SAS software program (SAS, 2004).

\section{RESULTS AND DISCUSSION}

\section{Measurement of carob pods and extraction yield}

The pod is light to dark brown, straight or slightly curved, with a thickened margin, and ranges from 10 to $20 \mathrm{~cm}$ in length and $1.5-2 \mathrm{~cm}$ in width. Results of carob pod measurements are shown in figure 2 and Table 1 . The two main carob pods constituents are pulp (89.86\%) and seeds (10.13\%) by weight. Carob seed constituents are hull (35.56\%), germ (24.64\%) and endosperm (39.76\%) the results are in good agreement with Dakia et al, 2008. The separation of the seed components furnished a higher yield of yellowish endosperm $39.74 \mathrm{~g} / 100 \mathrm{~g}$ of seed. The mean value of purified LBG yield was being $72.66 \%$ of dry endosperm and this is higher than the $51-61 \%$ yield range reported by (Dakia et al., 2008).

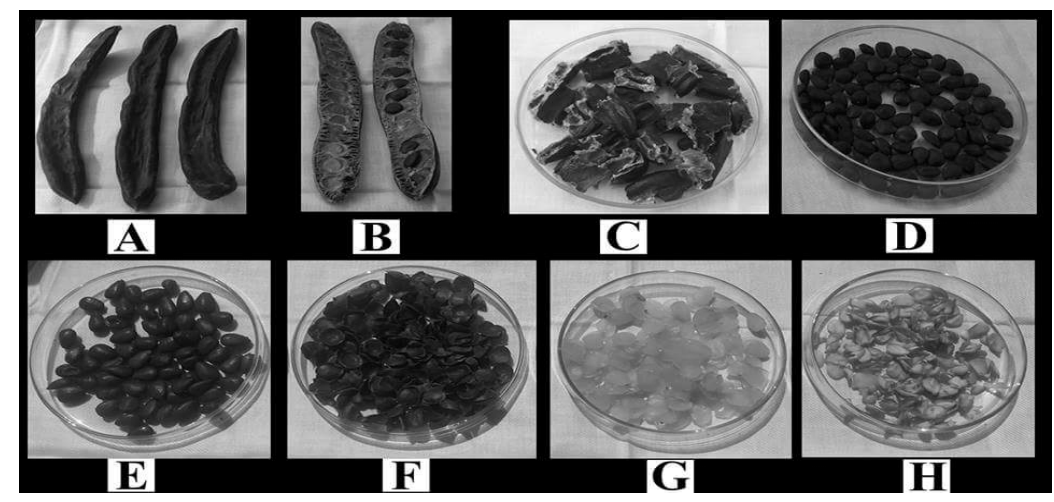

Figure 2. Images of carob A and B: Pods, C: crush Pulp, D: Seeds, E: Soaking seeds, F: Hull, G: Endosperm and H: Germ. 
Table 1. Measurement average of carob

\begin{tabular}{|c|c|c|}
\hline & Constitutes & Values (\%) \\
\hline \multirow[t]{3}{*}{ A- } & Pods & \\
\hline & 1- Pulp yield & $89.86 \pm 0.68$ \\
\hline & 2- Seeds yield & $10.13 \pm 0.68$ \\
\hline \multirow[t]{4}{*}{ B- } & Seeds & \\
\hline & 1- Hull (seed coat) & $35.56 \pm 0.52$ \\
\hline & 2- Germ (embryo) & $24.64 \pm 0.44$ \\
\hline & 3- Endosperm & $39.76 \pm 0.98$ \\
\hline \multirow[t]{2}{*}{ C- } & Endosperm & \\
\hline & purified LBG yield & $72.66 \pm 0.77$ \\
\hline
\end{tabular}

\section{Physico-chemical composition and microbiological analyses of carob dibis}

The physic-chemical composition of carob dibis is shown in Table (2). Revealed that the total solids matter was $73.55 \%$. The data showed that carob dibis is a rich source of sugars containing high concentrations of total sugars $(58.85 \%)$, reducing sugars (15.823\%), and non-reducing sugars (43.03\%). Simsek, (2000) also reported that carob dibis had $62.16-68.79 \%$ total sugars and $40.36-44.38 \%$ nonreducing sugar and also contained high amounts of total soluble solids (71Brix) this in principle is due to the high level of sugars and relatively low moisture content. Therefore, it is a good source of energy and can also be stored for a long time without deterioration.

High concentrations of minerals were found in carob dibis being $K$ $(1241.65 \mathrm{mg} / 100 \mathrm{~g})$, Na $(78.10 \mathrm{mg} / 100 \mathrm{~g}), \mathrm{Mg}(88.17 \mathrm{mg} / 100 \mathrm{~g})$, Ca $(314.90 \mathrm{mg} / 100 \mathrm{~g})$ and Fe $(2.63 \mathrm{mg} / 100 \mathrm{~g})$.

Also as shown in Table (2) the viscosity of carob dibis was $2913 \mathrm{cp}$.The colour $L$, a, and b values were $26.34,+1.83$ and +3.83 respectively. Therefore, a low redness (a) and a high Lightness ( $L$ ) value indicated that the dibis is of good quality. Simsek (2000) reported that $L, a, b$ values in carob dibis were18.28, $0.61,0.51$ respectively.

In addition, the total bacterial count was $258 \mathrm{cfu} / \mathrm{g}$; while, moulds and yeasts were not detected. 
Table 2. Physico-chemical composition and microbiological analyses of carob dibis

\begin{tabular}{|c|c|c|}
\hline \multicolumn{2}{|l|}{ Components } & Dibis \\
\hline \multicolumn{2}{|l|}{ Total solids (\%) } & $73.55 \pm 0.93$ \\
\hline \multicolumn{2}{|l|}{ Total soluble solids (Brix) } & $71.00 \pm 0.33$ \\
\hline \multicolumn{2}{|l|}{ Total sugar (\%) } & $58.85 \pm 0.69$ \\
\hline \multicolumn{2}{|l|}{ Reducing sugar (\%) } & $15.82 \pm 0.81$ \\
\hline \multicolumn{2}{|l|}{ Non reducing sugar (\%) } & $43.03 \pm 0.29$ \\
\hline \multicolumn{2}{|l|}{ Titritable acidity (\%) } & $0.87 \pm 0.013$ \\
\hline \multicolumn{2}{|l|}{$\mathrm{pH}$ value } & $5.18 \pm 0.011$ \\
\hline \multirow{7}{*}{ Minerals (mg/100g) } & $\mathrm{K}$ & 1241.65 \\
\hline & $\mathrm{Ca}$ & 314.90 \\
\hline & $\mathrm{Mg}$ & 88.17 \\
\hline & $\mathrm{Na}$ & 78.10 \\
\hline & $\mathrm{Fe}$ & 2.63 \\
\hline & $\mathrm{Zn}$ & 0.41 \\
\hline & $\mathrm{Mn}$ & 0.14 \\
\hline \multicolumn{2}{|l|}{ Viscosity (cp) } & 2913.00 \\
\hline \multicolumn{3}{|l|}{ Colour } \\
\hline \multicolumn{2}{|l|}{ L } & 26.34 \\
\hline \multicolumn{2}{|l|}{ a } & +1.83 \\
\hline \multicolumn{2}{|l|}{$b$} & +3.83 \\
\hline \multicolumn{2}{|l|}{ Total bacterial counts $(\mathrm{cfu} / \mathrm{g}$ ) } & $258 \pm 3.33$ \\
\hline \multicolumn{2}{|l|}{ Yeasts and moulds counts } & ND \\
\hline
\end{tabular}

cp: centipoise , (L): lightness, (+a): redness (+b): yellowness and ND: Not Detected

\section{Sensory evaluation of carob dibis}

As illustrated in Table (3) it could be noticed that carob dibis had a dark brown colour, with thick syrup texture like black honey, smells like mild chocolate, had a sweet taste and was very acceptable, providing a robust sweet flavour to many foods. The data are in good agreement with (Ersan and Nursel, 2005).

Table 3. Sensory evaluation of carob dibis

\begin{tabular}{|l|l|}
\hline Attributes & Carob dibis \\
\hline Colour & Dark brown liquid \\
Texture & Thick syrup \\
Odour & Smells like mild chocolate \\
Taste & Sweet \\
Acceptability & Very acceptable \\
\hline
\end{tabular}




\section{Chemical composition and microbiological analyses of LBG}

The chemical composition of LBG is presented in Table 4. It can be noted that the moisture content and total solids were $(11.17 \%$ and $88.82 \%)$ respectively. The crude protein content of LBG was (0.74\%). It appears that the purification process has largely reduced the protein content of LBG. The results show that LBG had lower amounts of non-carbohydrate components such as fat, crude fiber and ash. The total carbohydrates content of LBG was $96.96 \%$.

The data in Table (4) revealed that the LBG is considered a rich source of $K$, $\mathrm{Ca}, \mathrm{Mg}, \mathrm{Na}$ and Fe. Among the major minerals measured in LBG, $\mathrm{K}$ predominated (471.9 mg/100g) followed by high levels of $\mathrm{Ca}, \mathrm{Na}, \mathrm{Mg}$ and Fe $(157.61,130.35,55.21$ and $3.42 \mathrm{mg} / 100 \mathrm{~g}$ ), respectively. Levels of $\mathrm{Zn}$ and $\mathrm{Mn}$ were considerably lower (1.64 and $0.07 \mathrm{mg} / 100 \mathrm{~g}$ ), respectively. The data are in good agreement with (El-Shatnawi and Erifi, 2001).

In addition, the total bacterial count was $140.33(\mathrm{cfu} / \mathrm{g})$; while, moulds and yeasts were not detected. The low moisture content permitted better conservation of LBG powder and inhibited the development of bacteria.

Table 4. Chemical composition and microbiological analyses of LBG

\begin{tabular}{|c|c|c|}
\hline \multicolumn{2}{|l|}{ Components } & LBG \\
\hline \multicolumn{2}{|l|}{ Moisture (\%) } & $11.17 \pm 0.68$ \\
\hline \multicolumn{2}{|l|}{ Total solids (\%) } & $88.82 \pm 0.68$ \\
\hline \multicolumn{2}{|l|}{ Crude protein (\%) } & $0.74 \pm 0.07$ \\
\hline \multicolumn{2}{|l|}{ Fat (\%) } & $0.92 \pm 0.05$ \\
\hline \multicolumn{2}{|l|}{ Crude fiber (\%) } & $0.73 \pm 0.08$ \\
\hline \multicolumn{2}{|l|}{ Ash (\%) } & $0.65 \pm 0.08$ \\
\hline \multicolumn{2}{|l|}{ Total carbohydrate (\%) } & $96.96 \pm 0.15$ \\
\hline \multicolumn{2}{|l|}{$\mathrm{pH}$} & $5.25 \pm 0.01$ \\
\hline \multirow{7}{*}{ Minerals (mg/100g) } & $\mathrm{K}$ & 471.90 \\
\hline & $\mathrm{Ca}$ & 157.61 \\
\hline & $\mathrm{Na}$ & 130.35 \\
\hline & $\mathrm{Mg}$ & 55.21 \\
\hline & $\mathrm{Fe}$ & 3.42 \\
\hline & $\mathrm{Zn}$ & 1.64 \\
\hline & $\mathrm{Mn}$ & 0.07 \\
\hline \multicolumn{2}{|l|}{ Total bacterial counts (cfu/g ) } & $140.33 \pm 1.77$ \\
\hline \multicolumn{2}{|l|}{ Yeasts and moulds counts } & ND \\
\hline
\end{tabular}

ND: Not Detected 


\section{Physico-chemical analysis of plain yoghurt and LBG-10\% dibis yoghurt The pH}

Figure (3) showed the $\mathrm{pH}$ value of set yogurts during the storage period. In the present study, the $\mathrm{pH}$ of set yoghurt demonstrated wide variations during storage. The $\mathrm{pH}$ of plain yoghurts (C1) was higher than that prepared with $0.00 \% \mathrm{LBG}+10 \%$ dibis ( $\mathrm{C} 2$ ) during the storage period. This may be due to the presence of higher carbohydrate content in dibis being converted into acid during the fermentation process. The $\mathrm{pH}$ value of yoghurts and LBG-10\% dibis yoghurt increased with increasing of LBG concentration and during storage up to 9 days this may be due to high absorption of water by LBG and the water becomes unavailable for starter cultures. For this, it results in reducing the activity of starter cultures (Tamime and Robinson, 1999) and lactic acid production.

\section{Total solids contents}

The data in Figure (4) revealed that the total solids content of plain yoghurt and LBG-10\% dibis yoghurt was affected by addition of dibis, LBG and during storage. The total solids in all treatments ranged from $20.15 \%$ to $23.95 \%$ during storage period. The total solids content were higher in yoghurts with LBG-10\% dibis, compared with plain yoghurts (C1)and with $0.00 \%$ LBG $+10 \%$ dibis (C2) reflecting higher total solids content in treated yoghurts due to addition of dibis (73.55\% solids) and TS increased with increasing of LBG concentration. These results were in agreement with those obtained by Hande and Seher (2013). Moreover, there were increases in the total solids content with storage up to 6 days for all treatments. Increasing LBG levels led to increased total solids values. The functionality of hydrocolloids is demonstrated by their ability to bind water and prevent the free movement of water. Changes in total solids may affect certain other physico-chemical properties such as water holding capacity.

\section{Water-holding capacity (WHC)}

The results for the effect of dibis, various concentration of LBG and storage period on water holding capacity are shown in Figure (5). The plain yoghurt (C1) and that with $0.00 \%$ LBG $+10 \%$ dibis (C2) showed a lower increase in water holding capacity as compared to the yoghurt samples treated with various concentration of LBG-10\% dibis. Figure (5) shows that there was an increase in the water holding capacity of samples with the increase of LBG concentrations. Also, they increased during 9 days of storage for all treatments. The difference in WHC may be attributed to the properties of different proteins found in yoghurts. Interactions of water with proteins are very important in food systems because of their effects on the flavour and texture of foods. Stabilizers have two basic functions in yoghurt i.e. the 
binding of water and improvement in texture (Kumar and Mishra, 2004). Stabilizers bind with water to reduce water flow in the matrix space and some may interact with protein in the food matrix, and further increase hydration behavior (Tamime and Robinson, 1999). It was determined that LBG addition to the yoghurt led to the increment of water holding capacity.

Figure 3. pH values of plain yoghurt and LBG-dibis yoghurt during the storage period.

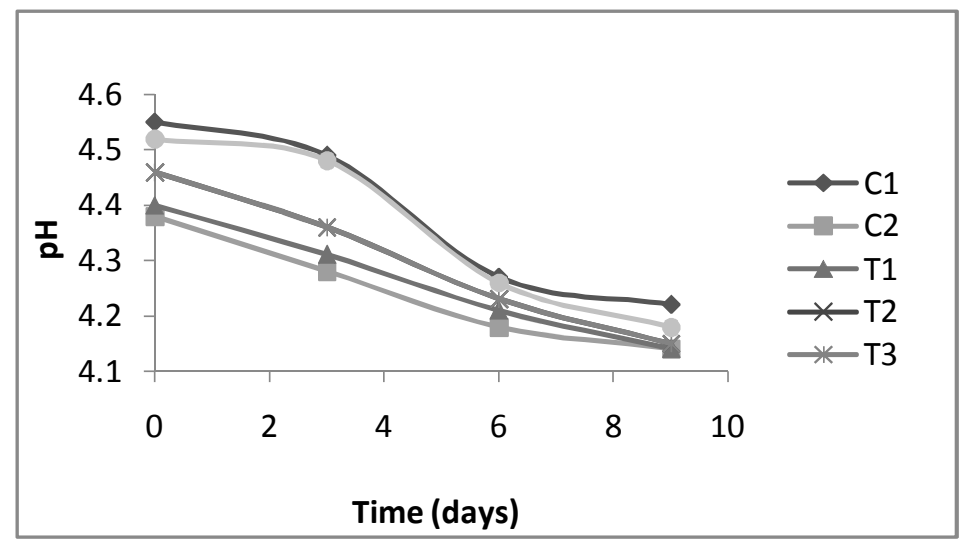

C1: control without dibis, C2: $0.00 \%$ LBG $+10 \%$ dibis, $T 1: 0.02 \%$ LBG $+10 \%$ dibis, $T 2$ : 0.04\% LBG+10\% dibis, T3: $0.06 \%$ LBG $+10 \%$ dibis and T4: $0.08 \%$ LBG $+10 \%$ dibis.

Figure 4. T.S values of plain yoghurt and LBG-dibis yoghurt during the storage period.

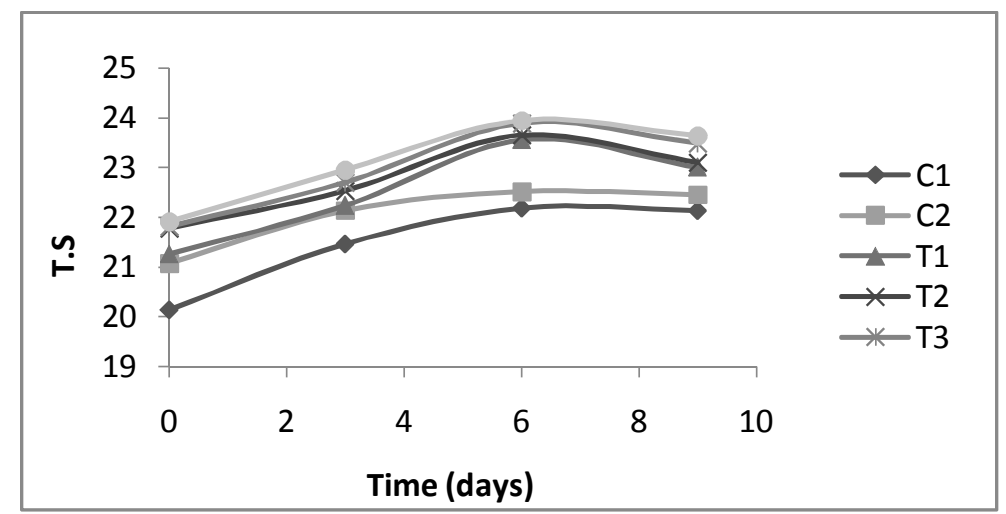

C1: control without dibis, C2: $0.00 \%$ LBG $+10 \%$ dibis, $\mathrm{T} 1: 0.02 \% \mathrm{LBG}+10 \%$ dibis, $\mathrm{T} 2$ : 0.04\% LBG+10\% dibis, T3: $0.06 \%$ LBG $+10 \%$ dibis and T4: $0.08 \%$ LBG $+10 \%$ dibis. 
Figure 5. WHC values of plain yoghurt and LBG-dibis yoghurt during the storage period

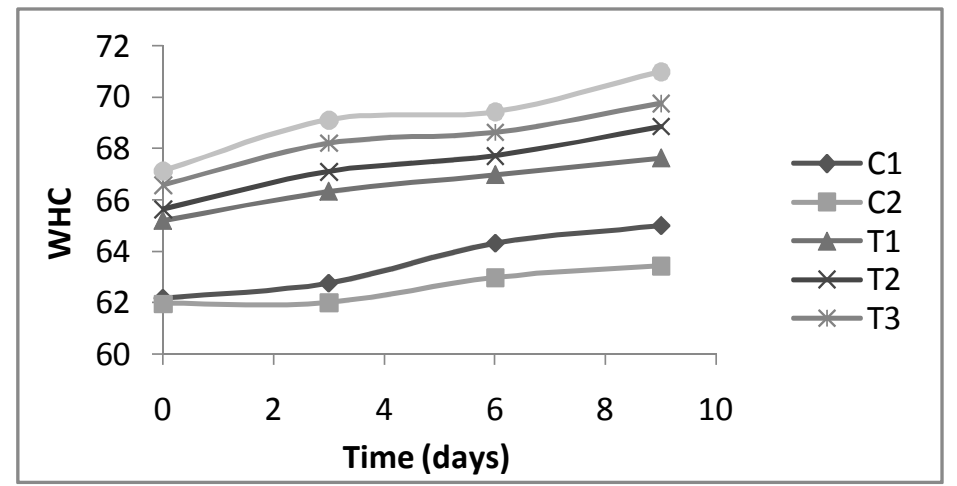

C1: control without dibis, C2: $0.00 \%$ LBG $+10 \%$ dibis, T1: $0.02 \%$ LBG $+10 \%$ dibis, T2: 0.04\% LBG+10\% dibis, T3: $0.06 \%$ LBG $+10 \%$ dibis and T4: $0.08 \%$ LBG $+10 \%$ dibis.

\section{Mineral content}

Data presented in Table (5) illustrate the minerals content of set yoghurt with dibis different concentration of LBG and during storage for 9 days. The obtained data show that $\mathrm{K}, \mathrm{Ca}, \mathrm{Mg}, \mathrm{Na}, \mathrm{Fe}, \mathrm{Zn}$ and $\mathrm{Mn}$ content of set yoghurt from all treatments increased with the addition of LBG-10\% dibis compared to the plain yoghurt (C1) during the storage period. The minerals content in dibis is higher than that of milk and the addition of dibis in yoghurts would indicate an increase in the final content of minerals. Yoghurt can also be a good source of essential nutrients such as minerals, especially zinc, in comparison with other dairy products (Yaman et al., 2005). The highest zinc content was found in set-yoghurt made with LBG-10\% dibis followed by set-yoghurt made with $0.00 \%$ LBG $+10 \%$ dibis (C2). Iron content in the presence of dibis and at various concentration of LBG was the highest while plain yoghurt (C1) was the lowest. Differences in the manganese content were also observed with the presence of dibis and at various concentration of LBG. 
Table 5. Minerals $(\mathrm{mg} / 100 \mathrm{~g})$ of plain yoghurt and LBG-10\% dibis yoghurt during fresh and after storage periods at 9 days.

\begin{tabular}{|c|c|c|c|c|c|c|c|}
\hline \multirow{2}{*}{ Components } & \multirow{2}{*}{$\begin{array}{l}\text { Storage } \\
\text { (days) }\end{array}$} & \multicolumn{2}{|c|}{ Control } & \multicolumn{4}{|c|}{ Percentage of added powder } \\
\hline & & $\mathrm{C} 1$ & $\mathrm{C} 2$ & $\mathrm{~T}_{1}$ & $\mathrm{~T}_{2}$ & $\mathrm{~T}_{3}$ & $\mathrm{~T}_{4}$ \\
\hline \multirow{2}{*}{ K } & Fresh & 214.22 & 422.33 & 423.33 & 423.36 & 423.38 & 423.56 \\
\hline & 9 & 226.38 & 431.45 & 432.26 & 432.28 & 432.38 & 432.45 \\
\hline \multirow{2}{*}{$\mathrm{Ca}$} & Fresh & 186.54 & 224.97 & 225.17 & 225.23 & 225.34 & 225.57 \\
\hline & 9 & 189.41 & 227.83 & 228.91 & 229.13 & 229.26 & 229.63 \\
\hline \multirow{2}{*}{$\mathrm{Mg}$} & Fresh & 13.35 & 18.98 & 19.68 & 19.72 & 19.74 & 19.88 \\
\hline & 9 & 14.91 & 20.32 & 20.44 & 20.52 & 20.58 & 20.62 \\
\hline \multirow{2}{*}{$\mathrm{Na}$} & Fresh & 60.38 & 62.04 & 62.54 & 62.64 & 62.72 & 62.78 \\
\hline & 9 & 63.76 & 64.21 & 64.61 & 64.68 & 64.74 & 64.80 \\
\hline \multirow{2}{*}{$\mathrm{Fe}$} & Fresh & 0.47 & 1.04 & 1.07 & 1.08 & 1.08 & 1.09 \\
\hline & 9 & 0.50 & 1.07 & 1.09 & 1.10 & 1.11 & 1.13 \\
\hline \multirow{2}{*}{$\mathrm{Zn}$} & Fresh & 3.43 & 4.17 & 4.19 & 4.22 & 4.24 & 4.27 \\
\hline & 9 & 3.46 & 4.20 & 4.21 & 4.23 & 4.25 & 4.29 \\
\hline \multirow{2}{*}{$\mathrm{Mn}$} & Fresh & 0.14 & 0.81 & 0.82 & 0.82 & 0.82 & 0.83 \\
\hline & 9 & 0.15 & 0.84 & 0.83 & 0.83 & 0.83 & 0.83 \\
\hline
\end{tabular}

C1: control without dibis, C2: $0.00 \%$ LBG $+10 \%$ dibis, $\mathrm{T} 1: 0.02 \%$ LBG $+10 \%$ dibis, T2: $0.04 \%$ LBG $+10 \%$ dibis, T3: $0.06 \%$ LBG $+10 \%$ dibis and T4: $0.08 \%$ LBG $+10 \%$ dibis.

\section{Rheological properties of yoghurts}

The effects of dibis, LBG and storage period on textural properties are shown in figure (5). Major parameter for evaluating textural characteristics of food are :

\section{Hardness}

Hardness ( $\mathrm{g}$ of the samples were obtained from the curves as the maximum force of the first compression) is a commonly evaluated parameter while determining yoghurt texture. Figure (6.a) Initial hardness of sample ranges from 37 to $55 \mathrm{~g}$. During storage period the hardness of yoghurt increased gradually up to 3 days of storage for all treatments then decreased till the end of storage period. LBG addition increased hardness values of yoghurts considerably. This can be explained by the presence of a mixed gel of LBG and casein and therefore its strength increases with LBG. The set yoghurt with $0.04 \%$ LBG $+10 \%$ dibis (T2) stored for 3 days had a higher hardness value than that containing higher concentration of LBG. Additionally, yoghurt produced by using $0.00 \% \mathrm{LBG}+10 \%$ dibis $(\mathrm{C} 2)$ gave the highest hardness values at the end of storage period among all treatments. The increase of hardness could be due to the reduction of $\mathrm{pH}$ during storage, causing the gel to contract and consequently increased gel firmness (Coggins et al., 2010). The hardness of yoghurt 
was found to be affected by the composition and $\mathrm{pH}$ of yoghurt. Positive correlation was found between hardness and total solids and $\mathrm{pH}$.

\section{Adhesiveness}

Yoghurt produced by using $0.00 \%$ LBG $+10 \%$ dibis (C2) and yoghurt with different concentration of LBG-dibis had the highest adhesiveness values at the 6 day of storage period than that of plain yoghurt without dibis (C1). Additionally, the set yoghurt with $0.04 \%$ LBG $+10 \%$ dibis (T2) at 6 and 9 days storage had higher adhesiveness values than that containing higher concentration of LBG. Decreases in adhesiveness appear to be related to the formation of a weak three-dimensional network caused by increasing LBG concentration. Probably, the high content of LBG reflected the low adhesiveness values for those samples and produced yogurt with soft and very low rubbing texture (Figure 6.b). The results revealed an inverse relationship between adhesiveness and hardness. The lowest and highest adhesiveness were observed in $\mathrm{T} 4$ and $\mathrm{T} 2$, respectively.

\section{Cohesiveness}

Cohesiveness, which is defined as the extent to which sample is deformed before its ruptures. The data in figure (6.c) show that cohesiveness of plain yoghurt (C1) or with $0.00 \%$ LBG $+10 \%$ dibis (C2) decreased during storage period. Cohesiveness showed negative correlation with T.S. Cohesiveness values of yoghurts were affected by LBG. Addition of LBG increased the cohesiveness values in set yoghurt with $0.06 \%$ and $0.08 \%$ LBG $+10 \%$ dibis (T3 and T4) after 3 days, and then decreased with the increase of storage period. Added LBG may be responsible for the observed differences in the cohesiveness.

\section{Springiness}

Springiness is the rate and extent to which a deformed material goes back to its initial condition after the deforming force is removed. Data in figure (6.d) show that the highest springiness was observed during 3 days of storage in all treatment then decreased through the 6 days of storage except for $0.06 \%$ LBG $+10 \%$ dibis (T3). Dibis and LBG addition influenced of springiness values of yoghurts. Data in figure (6.d) show that the springiness of set yoghurt with $0.04 \%$ LBG $+10 \%$ dibis (T2) stored for 3 days gained a higher value than that containing higher concentration of LBG.

\section{Gumminess}

Gumminess is the energy required to disintegrate a semi solid food product to a state ready for swallowing and is the product of hardness and cohesiveness. Gumminess in sample was affected by total solids content. Data in figure (6.e) show that the gumminess tended to increase during 3 days in all treatment except for plain 
yoghurt ( $\mathrm{C} 1$ ), and then decreased during storage period. The highest gumminess values were observed after 3 days of all treatment.

\section{Chewiness}

Chewiness showed similar trends of variations of gumminess. Data in figure (6.f) showed that the chewiness of yoghurt increased during 3 days of storage for all treatments then decreased tell the end of storage period.

Figure 6. Textural properties of plain yoghurt and with LBG-10\% dibis yoghurt during the storage period.

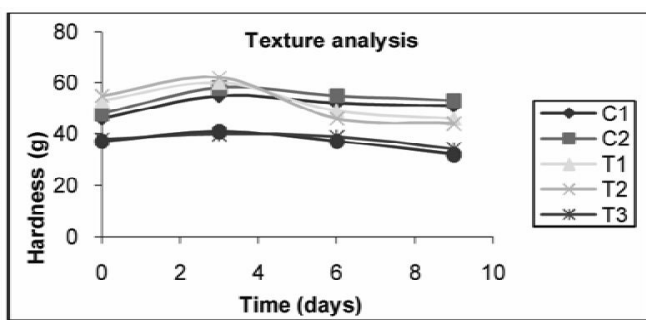

Figure (6.a)

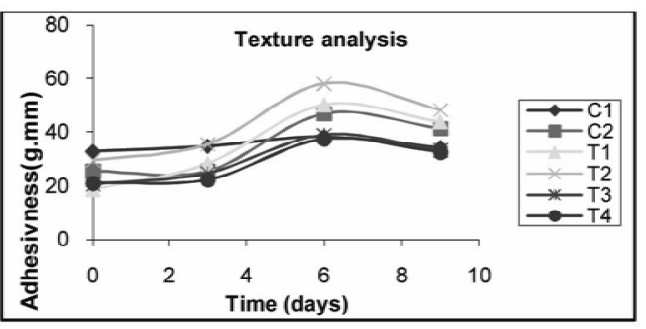

Figure (6.b)

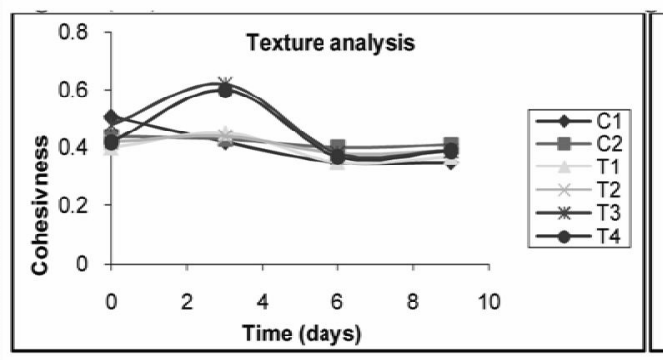

Figure (6.c)

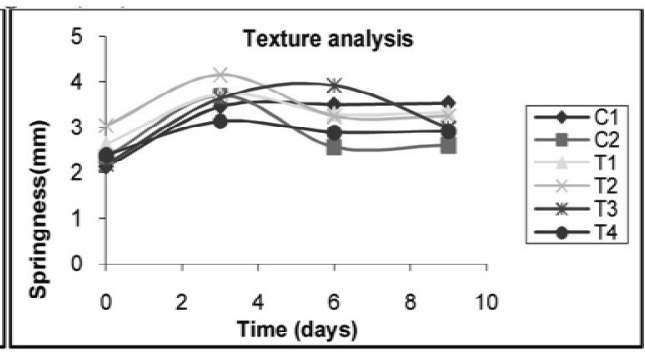

Figure (6.d)

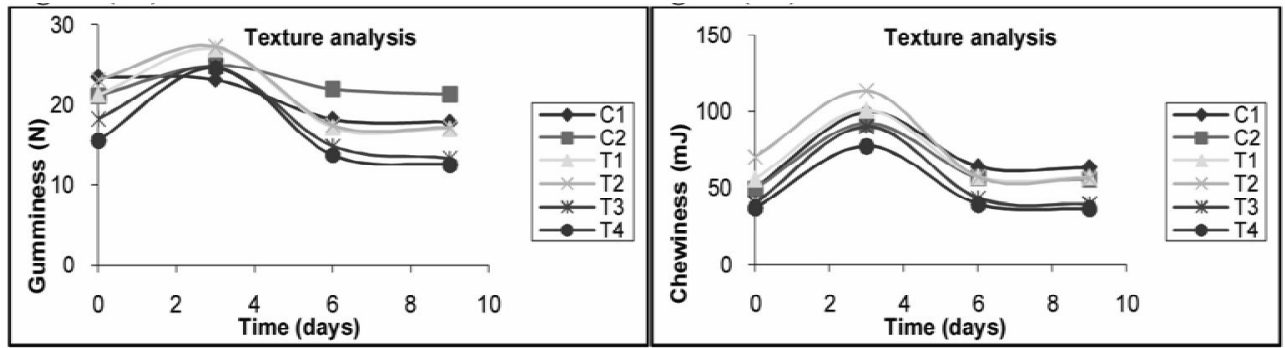

Figure (6.e)

Figure (6.f)

C1: control without dibis, C2: $0.00 \%$ LBG $+10 \%$ dibis, $\mathrm{T} 1: 0.02 \% \mathrm{LBG}+10 \%$ dibis, $\mathrm{T} 2$ : 0.04\% LBG+10\% dibis, T3: $0.06 \%$ LBG $+10 \%$ dibis and T4: $0.08 \%$ LBG $+10 \%$ dibis. 


\section{Microbiological analysis}

Microbiological analysis data presented in Table (7) included total bacterial, $L$. bulgaricus and $S$. thermophiles counts $(\mathrm{cfu} / \mathrm{g}$ ) of set-yoghurts during 9 days of storage period. The viable counts of total bacteria, S. thermophilus and L. bulgaricus in all yoghurt samples were above $8 \log _{10} \mathrm{cfu} / \mathrm{g}$.

The effect of addition of dibis and different ratio of LBG was not significant ( $P>0.05$ ) on total bacterial count during storage except storage for 6 days that show significance $(P<0.05)$ between $C 1, T 4$ and other treatments. The effect of storage period on total bacterial count at the same treatment was not significant $(P>0.05)$ except for $C_{2}$ and $T_{3}$ showed that significance $(P<0.05)$ between fresh and other storage period. The total viable bacterial count increased gradually till 6 days of storage for all treatments then decreased at the end of storage period. However, the total bacterial counts of set-yoghurt containing $0.00 \%$ LBG $+10 \%$ dibis (C2) and LBG in all concentration were higher than that of the control at the end of the storage period.

The data show that the variations in $L$. bulgaricus counts were not significancant $(P>0.05)$ among all treatments during storage period, the effect of storage period on L. bulgaricus count at the same treatment show was not significant $(P>0.05)$ except for $T_{3}$ that show significance $(P<0.05)$ between 6 and 9 days of storage. Results also show that differences Streptococcus thermophills counts were not significancant $(P>0.05)$ between all treatments at the same storage period. The counts of S. thermophilus and L. bulgaricus counts were increased after 6 days, and then decreased at the 9 day of storage in all treatments.

Mould and yeasts were not detected in any yoghurt samples during the storage period. Also the coliform bacteria were not detected in both fresh and till the end of the storage period in all treatments. This might be due to the severity of heat treatments of milk and the role of lactic acid bacteria in the preservation of the products. 
Table 7. Counts $\left(\log _{10} \mathrm{cfu} / \mathrm{g}\right.$ ) of total bacterial, L. bulgaricus and S. thermophills of plain yoghurt and LBG-10\% dibis yoghurt during the storage period.

\begin{tabular}{|c|c|c|c|c|}
\hline \multirow{2}{*}{ Treatments } & \multicolumn{4}{|c|}{ Storage period (days) } \\
\hline & Fresh & 3 & 6 & 9 \\
\hline \multicolumn{5}{|c|}{ Total bacterial count } \\
\hline $\mathrm{C} 1$ & $9.02 \pm 0.13^{\mathrm{A} \mathrm{a}}$ & $9.20 \pm 0.37^{\mathrm{A} \mathrm{a}}$ & $9.40 \pm 0.05^{\mathrm{B} \mathrm{a}}$ & $9.16 \pm 0.25^{\mathrm{A} \mathrm{a}}$ \\
\hline $\mathrm{C} 2$ & $9.08 \pm 0.08^{\mathrm{Ab}}$ & $9.43 \pm 0.04^{\mathrm{Aa}}$ & $9.40 \pm 0.04^{\mathrm{B} \mathrm{a}}$ & $9.24 \pm 0.24^{\mathrm{A} a b}$ \\
\hline $\mathrm{T} 1$ & $9.22 \pm 0.15^{\mathrm{Aa}}$ & $9.57 \pm 0.32^{\mathrm{Aa}}$ & $9.62 \pm 0.05^{\mathrm{AB} a}$ & $9.21 \pm 0.61^{\mathrm{A} \mathrm{a}}$ \\
\hline $\mathrm{T} 2$ & $9.30 \pm 0.24^{\mathrm{Aa}}$ & $9.69 \pm 0.21^{\mathrm{A} \mathrm{a}}$ & $9.71 \pm 0.31^{A B}$ a & $9.34 \pm 0.27^{\mathrm{A} \mathrm{a}}$ \\
\hline T3 & $9.21 \pm 0.03^{\mathrm{Ab}}$ & $9.62 \pm 0.05^{A a b}$ & $9.75 \pm 0.20 \mathrm{AB}$ a & $9.47 \pm 0.38^{\mathrm{A} a b}$ \\
\hline T4 & $9.34 \pm 0.35^{\mathrm{A} \mathrm{a}}$ & $9.72 \pm 0.45^{\mathrm{A} \mathrm{a}}$ & $9.89 \pm 0.14^{\mathrm{A} \mathrm{a}}$ & $9.48 \pm 0.42^{\mathrm{A} \mathrm{a}}$ \\
\hline \multicolumn{5}{|c|}{ L. delbrueckii subsp. bulgaricus count } \\
\hline $\mathrm{C} 1$ & $8.31 \pm 0.27^{\mathrm{Aa}}$ & $8.34 \pm 0.29^{\mathrm{Aa}}$ & $8.52 \pm 0.07^{\mathrm{A} \mathrm{a}}$ & $8.10 \pm 0.21^{\mathrm{Aa}}$ \\
\hline $\mathrm{C} 2$ & $8.32 \pm 0.33^{\mathrm{Aa}}$ & $8.39 \pm 0.05^{\mathrm{A} \mathrm{a}}$ & $8.53 \pm 0.54^{\mathrm{A} \mathrm{a}}$ & $7.94 \pm 0.04^{\mathrm{A} \mathrm{a}}$ \\
\hline $\mathrm{T} 1$ & $8.14 \pm 0.04^{\mathrm{Aa}}$ & $8.20 \pm 0.18^{\mathrm{Aa}}$ & $8.40 \pm 0.22^{\mathrm{A} \mathrm{a}}$ & $7.94 \pm 0.57^{\mathrm{A} \mathrm{a}}$ \\
\hline $\mathrm{T} 2$ & $8.12 \pm 0.04^{\mathrm{Aa}}$ & $8.20 \pm 0.03^{\mathrm{Aa}}$ & $8.34 \pm 0.35^{\mathrm{A} \mathrm{a}}$ & $8.04 \pm 0.43^{\mathrm{Aa}}$ \\
\hline T3 & $8.12 \pm 0.04^{A ~ a b}$ & $8.30 \pm 0.29^{A a b}$ & $8.43 \pm 0.35^{\mathrm{Aa}}$ & $7.97 \pm 0.07^{\mathrm{Ab}}$ \\
\hline T4 & $8.19 \pm 0.15^{\mathrm{Aa}}$ & $8.37 \pm 0.34^{\mathrm{Aa}}$ & $8.28 \pm 0.46^{\mathrm{A} \mathrm{a}}$ & $7.89 \pm 0.49 \mathrm{~A} \mathrm{a}$ \\
\hline \multicolumn{5}{|c|}{ S. thermophills count } \\
\hline $\mathrm{C} 1$ & $9.23 \pm 0.17^{\mathrm{Aa}}$ & $9.45 \pm 0.05^{\mathrm{Aa}}$ & $9.70 \pm 0.79^{\mathrm{A} \mathrm{a}}$ & $9.31 \pm 0.31^{\mathrm{Aa}}$ \\
\hline $\mathrm{C} 2$ & $9.44 \pm 0.45^{\mathrm{A} a b}$ & $9.53 \pm 0.04^{\mathrm{A} \mathrm{a}}$ & $9.58 \pm 0.08^{\mathrm{Aa}}$ & $9.05 \pm 0.17^{A b}$ \\
\hline $\mathrm{T}_{1}$ & $9.43 \pm 0.04^{\mathrm{A} a b}$ & $9.56 \pm 0.31^{\mathrm{Aab}}$ & $9.66 \pm 0.08^{\mathrm{Aa}}$ & $9.09 \pm 0.12^{\mathrm{Ab}}$ \\
\hline $\mathrm{T}_{2}$ & $9.40 \pm 0.45^{\mathrm{A} \mathrm{a}}$ & $9.43 \pm 0.05^{\mathrm{A} \mathrm{a}}$ & $9.68 \pm 0.37^{\mathrm{Aa}}$ & $8.98 \pm 0.16^{\mathrm{Ab}}$ \\
\hline $\mathrm{T}_{3}$ & $9.41 \pm 0.05^{\mathrm{Ab}}$ & $9.56 \pm 0.04^{\mathrm{A} a b}$ & $9.65 \pm 0.09^{\mathrm{A} \mathrm{a}}$ & $8.99 \pm 0.12^{\mathrm{Ac}}$ \\
\hline $\mathrm{T}_{4}$ & $9.43 \pm 0.04^{\mathrm{A} \mathrm{a}}$ & $9.55 \pm 0.23^{\mathrm{A} \mathrm{a}}$ & $9.64 \pm 0.085^{\mathrm{Aa}}$ & $8.97 \pm 0.17^{A ~ b}$ \\
\hline
\end{tabular}

${ }^{(A-B)}$ Different capital superscripts in the same column indicate significant differences $(P<0.05)$; ${ }^{(a-c)}$ Different lowercase superscripts in the same row indicate significant differences $(P<0.05)$. C1: control without dibis, C2: $0.00 \%$ LBG $+10 \%$ dibis, $\mathrm{T} 1: 0.02 \%$ LBG $+10 \%$ dibis, $\mathrm{T} 2: 0.04 \%$ LBG $+10 \%$ dibis, T3: $0.06 \%$ LBG+10\% dibis and T4: $0.08 \%$ LBG+10\% dibis.

\section{Sensory properties}

Data presented in Table 8 illustrated that the sensory properties of plain yoghurt (C1) and varying levels of LBG-10\% dibis yoghurt during storage period. The data revealed that, the sensory properties such as flavour, body \& texture, appearance \& colour and odour of plain yoghurt were affected by addition of LBG$10 \%$ dibis yoghurt with the varying of LBG concentrations and during storage periods. 


\section{Flavour and odour}

The obtained data showed that flavour and odour of the set yoghurts were significantly affected by the addition of dibis $(P<0.05)$, yoghurt containing dibis had higher scores for flavour and odour than that of plain yoghurt (C1). The addition of LBG had no significant affect (P > 0.05) on the yoghurt odour. El-Sayed et al., (2002) determined that the yoghurt produced with addition of xanthan gum had no adverse effect on flavour of yoghurt, whereas it did affect texture and body. The storage time had a positive effect on the flavour and odour which increased throughout 6 days of storage then decreased after 9 days storage period, but the increase and decrease of scores were not statistically significant for the treatments $(P>0.05)$.

\section{Body and texture}

The data revealed that, body and texture of the set yoghurts were significantly affected by the addition of LBG $10 \%$ dibis and throughout the storage period $(P<0.05)$. The score of LBG-10\% dibis yoghurt was higher in body and texture at all treatments compared to control sample. On the other hand, sample with high concentration of LBG $(0.08 \%$ LBG $+10 \%$ dibis (T4) had lower values than the other concentration of LBG. Stabilizers have two basic functions in yoghurt i.e. the binding of water and improvement in texture. Kumar and Mishra (2004) found that the addition of stabilizer to yoghurts improves texture and total acceptability.

\section{Appearance andcolour}

The data revealed that the scores for appearance and colour of plain yoghurt were higher than that of yoghurt with LBG $+10 \%$ dibis at all treatments. It is probable that the thickness of the product influenced eye appeal. In many food products, colour and appearance or eye appeal are the first indicator of quality and may contribute significantly to the decision of the consumer to accept or reject the product. The decrease of appearance and colour throughout the storage period was not statistically significant $(P>0.05)$

\section{Overall acceptability}

As shown in Table (8) overall scores of the set yoghurts were significantly affected by the addition LBG-10\% dibis and throughout the storage period and ( $\mathrm{P}<$ 0.05), the highest scores were given to the sample containing LBG at a concentration of $0.04 \%$ LBG $+10 \%$ dibis (T2), among yoghurt with other percentages of LBG while the plain yoghurt $(\mathrm{C} 1)$ had the lowest total score. 
Table 8. Sensory properties of set yoghurt and LBG-dibis yoghurts during the storage period.

\begin{tabular}{|c|c|c|c|c|}
\hline \multirow{2}{*}{ Treatments } & \multicolumn{4}{|c|}{ Storage period (days) } \\
\hline & Fresh & 3 & 6 & 9 \\
\hline \multicolumn{5}{|c|}{ Flavour (45) } \\
\hline $\mathrm{C} 1$ & $40.00 \pm 1.41^{\mathrm{C} \mathrm{a}}$ & $40.80 \pm 1.81^{\mathrm{C} \mathrm{a}}$ & $40.40 \pm 1.95^{\mathrm{Da}}$ & $39.30 \pm 1.25^{\mathrm{Da}}$ \\
\hline $\mathrm{C} 2$ & $43.00 \pm 1.03^{\mathrm{AB} a}$ & $43.80 \pm 1.22^{\mathrm{AB} a}$ & $43.70 \pm 1.25^{\mathrm{AB} a}$ & $43.50 \pm 1.08^{\mathrm{AB} a}$ \\
\hline $\mathrm{T}_{1}$ & $43.60 \pm 1.17^{\mathrm{AB} a}$ & $43.80 \pm 1.13^{\mathrm{AB} \mathrm{a}}$ & $43.90 \pm 0.73^{\mathrm{AB} a}$ & $43.00 \pm 1.76^{\mathrm{AB} \mathrm{a}}$ \\
\hline $\mathrm{T}_{2}$ & $44.40 \pm 0.84^{\mathrm{A} \mathrm{a}}$ & $44.60 \pm 0.70^{\mathrm{A} \mathrm{a}}$ & $44.30 \pm 0.82^{\mathrm{A} \mathrm{a}}$ & $43.90 \pm 0.73^{\mathrm{A} \mathrm{a}}$ \\
\hline $\mathrm{T}_{3}$ & $43.10 \pm 1.44^{\mathrm{B} a b}$ & $43.50 \pm 1.27^{\mathrm{AB} \mathrm{a}}$ & $42.90 \pm 0.87^{\mathrm{B} a b}$ & $42.50 \pm 1.08^{\mathrm{B} \mathrm{b}}$ \\
\hline $\mathrm{T}_{4}$ & $43.20 \pm 1.14^{\mathrm{AB} a}$ & $43.30 \pm 0.82^{\mathrm{Ba}}$ & $41.80 \pm 1.31^{\mathrm{Cb}}$ & $40.80 \pm 1.39^{\mathrm{cb}}$ \\
\hline \multicolumn{5}{|c|}{ Body and texture (35) } \\
\hline $\mathrm{C} 1$ & $25.00 \pm 1.33^{\mathrm{Da}}$ & $24.10 \pm 0.99^{\mathrm{D} a b}$ & $22.30 \pm 1.49^{\mathrm{D} \mathrm{bc}}$ & $22.00 \pm 1.49^{\mathrm{DC}}$ \\
\hline $\mathrm{C} 2$ & $28.10 \pm 1.66^{\mathrm{Ca}}$ & $27.10 \pm 1.37^{\mathrm{C} a b}$ & $26.10 \pm 0.73^{\mathrm{Cbc}}$ & $25.00 \pm 1.88^{\mathrm{Cc}}$ \\
\hline $\mathrm{T}_{1}$ & $30.00 \pm 1.49^{\mathrm{B} \mathrm{a}}$ & $28.80 \pm 1.31^{\mathrm{B} a b}$ & $28.10 \pm 1.79^{\mathrm{B} b c}$ & $27.00 \pm 1.63^{\mathrm{BC}}$ \\
\hline $\mathrm{T}_{2}$ & $32.00 \pm 1.41^{\mathrm{Aa}}$ & $31.10 \pm 0.73^{\mathrm{A} \mathrm{ab}}$ & $30.00 \pm 2.05^{\mathrm{Ab}}$ & $30.00 \pm 1.49^{\mathrm{Ab}}$ \\
\hline $\mathrm{T}_{3}$ & $30.60 \pm 2.17^{\mathrm{AB} a}$ & $30.80 \pm 2.65^{\mathrm{A} \mathrm{a}}$ & $27.80 \pm 1.39^{\mathrm{B} \mathrm{b}}$ & $25.80 \pm 1.31^{\mathrm{BC} C}$ \\
\hline $\mathrm{T}_{4}$ & $27.80 \pm 1.39^{\mathrm{Ca}}$ & $26.90 \pm 1.44^{\mathrm{Cab}}$ & $25.80 \pm 1.39^{\mathrm{Cb}}$ & $26.00 \pm 1.41^{\mathrm{BC} b}$ \\
\hline \multicolumn{5}{|c|}{ Appearance and colour(10) } \\
\hline $\mathrm{C} 1$ & $9.00 \pm 0.82^{\mathrm{Aa}}$ & $9.00 \pm 0.81^{\mathrm{Aa}}$ & $8.90 \pm 1.10^{\mathrm{A} \mathrm{a}}$ & $8.20 \pm 1.54^{\mathrm{A} \mathrm{a}}$ \\
\hline $\mathrm{C} 2$ & $8.10 \pm 0.73^{\mathrm{Aa}}$ & $7.40 \pm 1.07^{\mathrm{B} \mathrm{a}}$ & $8.20 \pm 1.55^{\mathrm{AB} a}$ & $8.00 \pm 1.41^{\mathrm{Aa}}$ \\
\hline $\mathrm{T}_{1}$ & $8.00 \pm 1.56^{\mathrm{A} \mathrm{a}}$ & $8.00 \pm 1.41^{\mathrm{AB} \mathrm{a}}$ & $8.10 \pm 1.45^{\mathrm{AB} a}$ & $8.00 \pm 1.69^{\mathrm{A} \mathrm{a}}$ \\
\hline $\mathrm{T}_{2}$ & $9.00 \pm 1.05^{\mathrm{Aa}}$ & $8.80 \pm 0.78^{\mathrm{Aa}}$ & $8.10 \pm 1.59^{\mathrm{AB} a}$ & $8.00 \pm 1.49^{\mathrm{A} \mathrm{a}}$ \\
\hline $\mathrm{T}_{3}$ & $8.00 \pm 1.49^{\mathrm{A} \mathrm{a}}$ & $8.00 \pm 1.05^{\mathrm{AB} a}$ & $7.00 \pm 1.49^{\mathrm{B} \mathrm{a}}$ & $7.00 \pm 1.63^{\mathrm{A} \mathrm{a}}$ \\
\hline $\mathrm{T}_{4}$ & $8.10 \pm 0.88^{\mathrm{A} \mathrm{a}}$ & $7.00 \pm 1.82^{\mathrm{B} \mathrm{a}}$ & $7.00 \pm 1.88^{\mathrm{Ba}}$ & $7.00 \pm 1.41^{\mathrm{Aa}}$ \\
\hline \multicolumn{5}{|c|}{ Odour (10) } \\
\hline $\mathrm{C} 1$ & $8.00 \pm 1.89^{\mathrm{A} \mathrm{a}}$ & $8.10 \pm 1.59^{\mathrm{A} \mathrm{a}}$ & $7.00 \pm 1.33^{\mathrm{B} \mathrm{a}}$ & $7.00 \pm 1.33^{\mathrm{B} \mathrm{a}}$ \\
\hline $\mathrm{C} 2$ & $9.00 \pm 1.33^{\mathrm{A} \mathrm{a}}$ & $8.90 \pm 1.44^{\mathrm{A} \mathrm{a}}$ & $8.20 \pm 1.31^{\mathrm{Aa}}$ & $8.20 \pm 1.39^{\mathrm{A} \mathrm{a}}$ \\
\hline $\mathrm{T}_{1}$ & $9.00 \pm 0.82^{\mathrm{Aa}}$ & $8.80 \pm 1.03^{\mathrm{A} \mathrm{a}}$ & $8.70 \pm 1.16^{\mathrm{A} \mathrm{a}}$ & $8.40 \pm 1.17^{\mathrm{A} \mathrm{a}}$ \\
\hline $\mathrm{T}_{2}$ & $9.10 \pm 0.73^{\mathrm{Aa}}$ & $9.00 \pm 0.82^{\mathrm{Aa}}$ & $8.90 \pm 1.00^{\mathrm{A} \mathrm{a}}$ & $8.80 \pm 1.22^{\mathrm{Aa}}$ \\
\hline $\mathrm{T}_{3}$ & $9.10 \pm 1.20^{\mathrm{A} \mathrm{a}}$ & $8.80 \pm 1.03^{\mathrm{Aa}}$ & $8.80 \pm 1.14^{\mathrm{Aa}}$ & $8.30 \pm 1.15^{\mathrm{Aa}}$ \\
\hline $\mathrm{T}_{4}$ & $8.90 \pm 0.99^{\mathrm{A} \mathrm{a}}$ & $8.70 \pm 1.16^{\mathrm{Aa}}$ & $8.60 \pm 1.26^{\mathrm{Aa}}$ & $8.00 \pm 1.15^{\mathrm{AB} \mathrm{a}}$ \\
\hline \multicolumn{5}{|c|}{ Overall scores (100) } \\
\hline $\mathrm{C} 1$ & $81.1 \pm 3.03^{\mathrm{Ca}}$ & $80.40 \pm 1.84^{\mathrm{E} a b}$ & $76.50 \pm 3.57^{\mathrm{E} \mathrm{cb}}$ & $76.50 \pm 3.56^{\mathrm{Ec}}$ \\
\hline $\mathrm{C} 2$ & $89.90 \pm 2.60^{\mathrm{B} \mathrm{a}}$ & $88.80 \pm 3.67^{\mathrm{Ca}}$ & $86.10 \pm 2.07^{\mathrm{Cb}}$ & $84.70 \pm 1.41^{\mathrm{BC} \mathrm{b}}$ \\
\hline $\mathrm{T}_{1}$ & $90.60 \pm 3.13^{\mathrm{B} \mathrm{a}}$ & $89.40 \pm 2.22^{\mathrm{BC} \mathrm{a}}$ & $88.80 \pm 2.53^{\mathrm{B} a b}$ & $86.40 \pm 3.47^{\mathrm{B} \mathrm{b}}$ \\
\hline $\mathrm{T}_{2}$ & $94.50 \pm 2.01^{\mathrm{Aa}}$ & $93.50 \pm 0.85^{\mathrm{A} a b}$ & $92.10 \pm 2.64^{\mathrm{Abc}}$ & $90.70 \pm 1.88^{A c}$ \\
\hline $\mathrm{T}_{3}$ & $90.80 \pm 3.36^{\mathrm{Ba}}$ & $91.10 \pm 2.51^{\mathrm{B} \mathrm{a}}$ & $86.50 \pm 2.06^{\mathrm{BC} b}$ & $83.60 \pm 1.77^{\mathrm{CD} c}$ \\
\hline $\mathrm{T}_{4}$ & $88.00 \pm 1.82^{\mathrm{B} \mathrm{a}}$ & $85.90 \pm 1.60^{\mathrm{Da}}$ & $83.20 \pm 3.15^{\mathrm{Db}}$ & $81.80 \pm 2.78^{\mathrm{Db}}$ \\
\hline
\end{tabular}

(A-E) Different capital superscripts in the same column indicate significant differences $(P<0.05)$;

(a-c) Different lowercase superscripts in the same row indicate significant differences $(P<0.05)$.

C1: control without dibis, C2: $0.00 \%$ LBG $+10 \%$ dibis, T1: $0.02 \%$ LBG $+10 \%$ dibis, T2: $0.04 \%$ LBG $+10 \%$ dibis, T3: $0.06 \%$ LBG $+10 \%$ dibis and T4: $0.08 \%$ LBG+10\% dibis. 


\section{CONCLUSION}

The results of this study show that Carob dibis is a rich source of sugars and contains high concentrations of minerals. This indicates that carob can be used as a good source of nutrients for humans. From these results, it could be concluded that the use of LBG as a thickening agent and stabilizer improved physicochemical, rheological properties and sensory properties of set yoghurt and thus supporting the application of carob gum in the production of fermented dairy products. Also yoghurt produced by addition of $0.04 \%$ LBG $+10 \%$ dibis had the highest score of sensory evaluation followed by $0.02 \%$ LBG $+10 \%$ dibis in yoghurt manufacture.

\section{REFERENCES}

1. AOAC. 2007. Official Methods of Analysis of the AOAC. International $18^{\text {th }} \mathrm{Ed}$. Gaithersburg, Maryland, USA.

2. Arslan, S. and Ozel, S. 2012. Some properties of stirred yoghurt made with processed grape seed powder, carrot juice or a mixture of grape seed powder and carrot juice. Milchwissenschaft., 67 (3):281-285.

3. Bourne, M. C. 1978. Texture profile analysis. Food Technology. 32: 62-72.

4. Bouzouita, N., Khadi, A., Zgoulli, S., Chebil, L., Chekki, R., Chaabouni, M. M. and Thonart, P. 2007. The Analysis of Crude and Purified Locust Bean Gum: A Comparison of Samples from Different Carob Tree Populations in Tunisia. Food Chem., 101: 1508-1515.

5. Cinbas A, Yazici F. 2008. Effect of the addition of blueberries on selected phisicochemical and sensory properties of yoghurt. Journal of Food Technology and Biotechnology, 46(4), 434-441.

6. Coggins, P. C., Rowe, D.E., Wilson, J.C. and Kumari, S. 2010. Storage and temperature effects on appearance and textural characteristics of conventional milk yoghurt. Journal of Sensory Studies. 25:549-576.

7. Dakia, P. A., Blecker, Ch., Robert, Ch., Wathelet, B. and Paquot, M. 2008. Composition and Physicochemical Properties of Locust Bean Gum Extracted from Whole Seeds by Acid or Water Dehulling Pre-treatment. Food Hydrocol., 22: 807-818.

8. El-Sayed, E. M., Abd El-Gawad, I. A., Murad, H. A. and Salah, S. H. 2002. Utilization of laboratory-produced xanthan gum in the manufacture of yoghurt and soy yoghurt. Eur. Food Res. Technol. 215:298-304.

9. El-Shatnawi, M. J. and Erifi, K. I. 2001. Chemical composition and livestock injestion of carob (Ceratonia Siliqua L.) Seeds. J. of Range Management. 54 (8): $669-673$. 
10. Ersan, K and Nursel, I. 2005. Pekmez: A Traditional Concentrated Fruit Product. Food Reviews International, Vol. 21, 357-366.

11. Hande, P and Seher, A. 2013. Effects of addition of locust bean gum on sensory, chemical, and physical properties of low-fat yoghurt. Journal of Food, Agriculture \& Environment. Vol.11 (2): 274-277.

12. Karaca, O.B. 2013. Effects of different prebiotic stabilizers and molasses types on physicochemical, sensory, colour and mineral characteristics of probiotic set yoghurts. Int. J. Dairy Technol. 66:1-8.

13. Karima, D., Manel, B., Ismail, A., Faten, R., David, P., Enrique, B., Carmen, E., Sami, F. 2014. Sucrose supplementation during traditional carob syrup processing affected its chemical characteristics and biological activities. LWT - Food Science and Technology 57:1-8

14. Kök, M. S. 2007. A comparative Study on the Compositions of Crude and Refined Locust Bean Gum: In Relation to Rheological Properties. Carbohydrate Poly. 70: 68-76.

15. Kumar, P. and Mishra H. 2004. Mango soy fortified set yoghurt: effect of stabilizer addition on physicochemical, sensory and textural properties. Food Chemistry, 87(4):501-507

16. Lucey, J.A. 2004. Cultured dairy products: An overview of their gelation and texture properties. Int. J. Dairy Technol. 57:77-84.

17. Marshal, R. T. 1992. Standard Methods for Examination of Dairy Products $16^{\text {th }}$ ed. American Public Health Association Washington, D.C.

18. Marth, E.H. 1998. Extended shelf life refrigerated foods microbiological quality and safety. A sientific status summary by the institute of food technologists' expert panel on food safety and nutrition. Chicago, ш. Food Technol. 52(2): 5762.

19. Ranadheera, S.; Evans, C.A.; Adams, M.C.; Baines, S.K. 2012. Probiotic viability and physico- chemical and sensory properties of plain and stirred fruit yogurts made from goat's milk. . Food Chem., 135, 1411-1418.

20. SAS. 2004. SAS Institute Inc. SAS/ETS® 9.1 User'SAS Institute Inc. 2004. SAS/ETS $® 9.1$ User's Guide. Cary, NC.

21. Simsek A. 2000. Research on the composition of different fruit concentrate. Master's Thesis, Ankara University Graduate School of Natural and Applied Sciences, Ankara, Turkey, p, (In Turkish)

22. Tamime, A.Y. and Robinson, R. K. 1999. Yoghurt: Science and Technology. Woodhead Publishing, Cambridge, p 619.

23. Yaman M, Durak $M$ and Bakirdere S. 2005. Comparison of dry, wet, and microwave ashing methods for the determination of $\mathrm{Al}, \mathrm{Zn}$, and $\mathrm{Fe}$ in yogurt samples by atomic absorption spectrometry. Spectroscopy Letters. 38: 405-417. 


\section{انتاج وتنقية صمغ دبس الخروب واستخد/مهما في صناعة الزبادى}

وداد محمد الخولى' ، رضا عبد الحكيم عامز' مصطقى عبد المنعم زيدان '

$$
\text { ا - قسم بحوث الالبان - معهد بحوث تكنولوجيا الاغذية - مركز البحوث الزراعية }
$$

r - قسم بحوث تكنولوجيا الحاصلاات البستانية - معهد بحوث تكنولوجيا الالبان - مركز البحوث الزراعية

يستخدم صمغ الخروب فى الصناعات الغذائية كمواد مكثفة أو مغلطة للقوام ، مثبتات ، مستحلبات و عو امل جلتته وقد نم المو افقه على استخدامه لهذه الاغر اض فى العديد من الدول .ولذلك كان الهدف من هذه الار اسة هو انتاج دبس الخروب ، فصل ونتقية صمغ الخروب من البذرة ثم در اسة تأثثر اضافة دبس الخروب بنسبة 10\% و اضافة صمغ الخروب النقى بنسب 0.00 ، 0.02، 0.04 ، 0.06 ، 0.08) \% ع ع ، الجو امد الصلبة ، قوه ربط الماء ، محتوى المعادن ، الخو اص الريولوجية والتحاليل الميكروبيولوجية بالاضافة الى الخو اص العضوية الحسية للزبادى المصنع وذللك خلال فترات التخزين لمدة 9 ايام . اظهرت النتائج ان اضافة دبس وصمغ الخروب له تأثير على pH ، قو ام ربط الماء تز اوحت بين 20.15- 23.95 \% وذلك خلال فنز ات التخزين . اضافة دبس وصمغ الخروب لم يكن له تأثثرمعنوى على محتوى الزبادى من البكتريا تحت الدراسة ـ من النتائج المتحصل عليها اتضح ان دبس الخروب مصدر جيد للسكريات و المعادن وان افضل معاملة هى 0.04 \% صمغ خروب نقى مضاف اليه 10\% دبس وذلك من حيث الخواص الريولوجيه و الحسية وذلك بالمقارنه بباقى المعاملات . 